SHORT REPORT

\title{
Potential effects on human health of an ammonia rich atmospheric environment in an archaeologically important cave in southeast Asia
}

\section{F B Pyatt}

Occup Environ Med 2003;60:986-988

This important cave is described together with an analysis of the potential health effects for humans inhabiting an ecosystem, albeit on a temporary basis, possessing an ammonia rich atmospheric environment. The work emphasises potential environmental hazards together with an evaluation of the range of clinical effects. The environmental pollution in this cave is generally unlikely to have marked adverse effects on temporary visitors who lack pre-existing respiratory impairments. It is suggested that ancient humans would, to avoid an unpleasant polluted environment, have confined most of their activities to the outer regions of the cave. Comparisons are made with other ammonia contaminated environments.

A spects of the archaeology, ecology, and environmental science of the Niah caves of Sarawak (Borneo) have been researched by a number of workers. ${ }^{1-4}$ The caves lie within limestone; the Great Cave has received much attention since Harrisson's team, in the 1950s, located a human skull (the so-called "Deep Skull") and associated carbon generated a date of some 40000 radio-carbon years before the present..$^{5-11}$ The skull was located towards the outer edge of the cave.

The Great Cave has a floor area of approximately 10 ha and attains heights of $75 \mathrm{~m} .^{3}$ The West Mouth is a single large entrance, while there are four main entrances to the eastern and southern sides. The caves are inhabited by invertebrates and vertebrates. Bats and swiftlets are particularly evident and are important ecologically and economically; they provide income for people inhabiting nearby long houses, who collect both guano (as a fertiliser) and swiftlets' nests (for bird's nest soup production)—such individuals are exposed to occupational pollution. The guano, derived from bats and swiftlets has been accumulating in the vast cave system for a prolonged period and consequently extensive deposits are present.

Ammonia is a normal constituent of the atmospheric environment; it is produced by the decomposition of organic wastes, through anthropogenic activities such as fuel combustion, and in processes concerned with the generation and utilisation of ammonia. The "normal" atmospheric concentration for ammonia has been reported ${ }^{12}$ as $20 \mu \mathrm{g} /$ $\mathrm{m}^{3}$. This paper examines the atmospheric concentration of ammonia and assesses potential effects on humans inhabiting the cave in ancient times and entering it for various purposes in modern times; comparisons are drawn with other ammonia rich environments.

\section{METHODS}

Ammonia concentrations (minimum of three replicates in each case unless variation in concentration was detected) were determined in both 2000 and 2002 at various distances into the cave and at heights of 0,1 , and $2 \mathrm{~m}$ above ground; the results are presented in tables $1-4$. Ammonia concentrations were determined at noon in each case by means of a Draeger portable monitoring system which was checked against known concentrations of ammonia before and after usage. Dewey and colleagues ${ }^{13}$ also used Draeger tubes and pHydrion tests to monitor ammonia in animal rearing barns, and noted their high accuracy.

\section{RESULTS}

There was a reduction in ammonia concentration with increasing vertical height from the guano deposits; thus at $200 \mathrm{~m}$ into the cave, the concentrations shown in table 2 were determined. In 2002, air gently flowed into the cave environment from the north, at a velocity of about $0.7 \mathrm{~m} / \mathrm{s}$, and hence diluted the concentration of ammonia (see table 3). Table 4 shows ammonia concentration at various heights above guano surface.

Water was positioned in plastic containers and left for a period of seven days.

The initial pH was 5.65 and changes to between $\mathrm{pH} 5.85$ to pH 7.4 were noted.

\section{CONCLUSIONS}

Silverman ${ }^{14}$ studied seven human males exposed to ammonia at $350000 \mu \mathrm{g} / \mathrm{m}^{3}$ and reported an impairment of respiration and nose and throat irritation; Jacobs ${ }^{15}$ noted that ammonia inhalation affects mainly the upper respiratory tract; and Miner $^{12}$ indicated that, at enhanced concentrations ammonia is an asphyxiant. Friberg ${ }^{16}$ noted that the inhibition of cilia activity was reversible unless the concentration exceeded $210000 \mu \mathrm{g} / \mathrm{m}^{3}$; these observations have implications in terms of access to unpolluted air when working in ammonia polluted sites such as caves with enhanced guano increments. Ammonia can cause damage when it dissolves in water to yield a strongly alkaline solution: $\mathrm{NH}_{3}+\mathrm{H}_{2} \mathrm{O} \rightarrow$ $\mathrm{NH}_{4} \mathrm{OH}$. This exothermic reaction generates thermal injury and its extent is affected by gaseous concentration, exposure duration, extent of inhalation, synergism/addition with other pollutants, general health of the exposed individual, and recovery potentials, for example, transfer to unpolluted air.

Additional important health reviews include those of Caplin, ${ }^{17} \mathrm{O}^{\prime} \mathrm{Kane}^{18}$ Arwood and colleagues, ${ }^{19}$ Klein and colleagues, ${ }^{20}$ and Swotinsky and Chase. ${ }^{21}$

McFarlane and colleagues ${ }^{22}$ worked in a $170 \mathrm{~m}$ long bat inhabited Mexican cave (Cueva del Tigre); they reported atmospheric ammonia concentrations at a massive 1338$1779 \mathrm{ppm}$. They note that ammonia volatilisation is an important biogeochemical pathway in dry bat cave ecosystems and accounts for the removal of most of the urea derived nitrogen. The reported concentrations are enhanced compared with Niah (tables 1-4) and represent potential 
Main messages

- The atmosphere of the Niah cave in Sarawak, Borneo is polluted by ammonia; it is visited by individuals for the collection of guano and birds' nests, and for recreation.

- Concentrations of ammonia in the cave environment vary markedly, and potentially can adversely affect those with pre-existing respiratory impairments.

- The ammonia generates environmental and occupational pollution problems and comparisons are made with other ammonia polluted environments.

- Ancient humans, inhabiting such caves, would have confined most of their activities to the outer, less polluted, regions.

health hazards for visitors. As in Niah, ammonia concentrations are enhanced as the cave is penetrated; Niah varies from values of $<0.25 \mathrm{ppm}$ at $0 \mathrm{~m}$ to $54 \mathrm{ppm}$ at $500 \mathrm{~m}$ (tables 1 and 3), while Cueva del Tigre varies from $50 \mathrm{ppm}$ adjacent to the cave mouth to $1779 \mathrm{ppm}$ deep within the cave. There is possibly greater ammonia production within Cueva del Tigre and/or poorer dispersion of ammonia, due to factors such as the shape of the cave which has a pronounced dog-leg. However, this does not explain the marked difference between the mouth of the Niah cave and station 3 in Cueva del Tigre. The explanation for these remarkable differences, in two systems extremely rich in guano, may be related to the fact that the atmosphere in the Niah cave is not permanently resident but can exit/diffuse via one or more of several exits/entrances largely independent of wind direction. Certainly, an examination of table 1 (2000 data, collected during a period of air stagnation) and table 3 (2002) illustrates the dilution effect of in-flowing air on the ammonia concentration of the cave atmosphere. In Cueva del Tigra, with a single opening and a dog-leg, it is conceivable that the cave atmosphere is resident for a longer

Table 1 Ammonia concentrations in the cave environment (2000)

\begin{tabular}{lll}
\hline $\begin{array}{l}\text { Distance into } \\
\text { cave }(\mathrm{m})\end{array}$ & Conc. $(\mathrm{ppm})$ & Conc. $\left(\mu \mathrm{g} / \mathrm{m}^{3}\right)$ \\
\hline 0 & $<0.25^{*}$ & $<177.5$ \\
50 & 12 & 8520 \\
200 & $32-33$ & $22720-23430$ \\
500 & $51-54$ & $36210-38340$ \\
\hline
\end{tabular}

${ }^{*}$ This is the lower limit of detection. The results were obtained during a period of air stagnation - that is, no detectable air flow within or adjacent to the cave environment. Nevertheless it should be noted that the atmospheric environment of the cave will be subject to turbulence due to the movement of organisms such as swifflets, bats, and humans, and normal, however weak, diurnal heating/cooling processes.

Table 2 Change in ammonia concentration with increasing vertical height at site $200 \mathrm{~m}$ into the cave

\begin{tabular}{lll}
\hline Vertical height $(\mathrm{m})$ & Conc. (ppm) & Conc. $\left(\mu \mathrm{g} / \mathrm{m}^{3}\right)$ \\
\hline 0 & $39-41$ & $27690-29110$ \\
1 & 37 & 26270 \\
2 & 33 & 23430 \\
\hline
\end{tabular}

Policy implications

- There is a need to monitor ammonia concentrations and assess health implications for individuals entering the cave for occupational and recreational activities. The importance of both synergism and cave ventilation is paramount. Toxic gases probably affected the distribution of ancient humans within cave environments.

period and that arguably there is very limited exchange of cave air with the outside environment; thus significant concentrations of ammonia can develop.

While Cueva del Tigre has an atmosphere exceeding the TLV for ammonia ( $25 \mathrm{ppm}$ ) and thus potentially represents a threat to human health, the Niah cave does not generate this problem although the atmosphere may adversely affect those with pre-existing respiratory impairments. However, the additional possibility exists that even at comparatively low concentrations of ammonia, adverse effects of ammonia may occur where synergistic reactions with, for example, airborne particulates derived from atmospheric erosion or generated by disturbance resultant from extraction activities of the massive guano beds occurs. Such disturbance may result from various activities, but guano collection (for fertiliser) is likely to be a major contributory influence. Another factor would be trampling (including scuffing of feet), which might also cause less problematical compaction; atmospheric erosion can occur during periods of high turbulence which may well have occurred episodically in the past.

Ammonia is present in Niah in concentrations in excess of the odour threshold and can generate irritant effects. It is conceivable that in the past humans confined most of their activities to the more congenial atmospheric environment to be found nearer the mouth of the cave rather than in the deeper, darker locations, and it is interesting to note that the "Deep Skull" was found near the mouth of the cave; other artefacts have also been located in this area. ${ }^{3}$ Furthermore, if early humans were using fires, the gaseous and particulate

Table 3 Ammonia concentrations in the cave environment (2002)

\begin{tabular}{lll}
\hline Distance into cave $(\mathrm{m})$ & Conc. $(\mathbf{p p m})$ & Conc. $\left(\boldsymbol{\mu g} / \mathrm{m}^{3}\right)$ \\
\hline 0 & 0.0 & 0 \\
10 & $<0.25$ & 177.5 \\
50 & $<0.25$ & 177.5 \\
150 & 1.8 & 1278 \\
200 & 2.1 & 1491 \\
200 & 4.0 & 2840 \\
(in freshly excavated pit) & 8.0 & 5680 \\
\hline
\end{tabular}

Table 4 Change in ammonia concentration (ppm) with increasing vertical height (2002)

\begin{tabular}{|c|c|c|c|}
\hline \multirow{2}{*}{$\begin{array}{l}\text { Distance into } \\
\text { cave }(\mathrm{m})\end{array}$} & \multicolumn{3}{|c|}{ Height } \\
\hline & $0 \mathrm{~m}$ & $1 \mathrm{~m}$ & $2 \mathrm{~m}$ \\
\hline 0 & 0 & 0 & 0 \\
\hline 50 & 0.4 & 0.2 & 0.2 \\
\hline 150 & 2.3 & 1.9 & 1.8 \\
\hline 200 & 2.4 & 2.2 & 2.1 \\
\hline
\end{tabular}


pollutants would be unpleasant in the relatively confined space and could act synergistically with the ammonia, further aggravating potential adverse health effects.

Surveys of visitors to the caves were carried out in 2000 and 2002 and effects reported in a small sample $(n=40)$ included headaches, dry throats, sore throats, dry coughs, productive coughs, dizziness, watering eyes, etc. However, such symptoms could be due to exposure to conditions beyond the cave environment; it is considered that there are no likely causes for significant adverse pollutant induced health effects for occasional visitors to the cave who are in good health and do not spend extensive periods within the cave. Indeed these effects are in agreement with those described by Schiffman, ${ }^{23}$ who reviewed health effects of livestock odours on humans and recorded eye, throat, and nose irritation, headache, drowsiness, and potential effects on mood and memory. Kirkhorn and Garry, ${ }^{24}$ however, noted that fungal spores and bacterial endotoxins may be generated by animal confinement and cause upper and lower airway inflammation; they list the effects of organic dusts and animal confinement gases on humans as respiratory diseases and syndromes such as hypersensitivity pneumonitis, mucous membrane inflammation syndrome, organic dust toxic syndrome, chronic bronchitis, and asthma-like syndrome. Dewey and colleagues, ${ }^{13}$ investigating animal rearing barns, reported that ammonia concentrations in $52 \%$ of the cases "exceeded $7.5 \mathrm{ppm}$; ammonia concentrations greater than $7.5 \mathrm{ppm}$ are associated with respiratory problems in humans". This serves to illustrate that there are some discrepancies concerning ammonia concentrations likely to generate adverse health effects in humans. Indeed, Donham and colleagues ${ }^{25}$ reported that in the pig industry, research has indicated exposure limit recommendations of $2.5 \mathrm{mg} / \mathrm{m}^{3}$ for total dust, $0.23 \mathrm{mg} / \mathrm{m}^{3}$ for respirable dust, and $7 \mathrm{ppm}$ for ammonia. In the poultry industry, they found "significant pulmonary function decrements with 12 ppm ammonia". Michaels ${ }^{26}$ evaluated the toxicity of ammonia based on anecdotal data, reconstructions of contemporary industrial accidents, and animal bioassays and reported an example of $33737 \mathrm{ppm}, \mathrm{v} / \mathrm{v}$, which had a 5 minute zero mortality value in one major ammonia release episode.

In conclusion, this guano-rich cave has a rich ammonia atmosphere which is affected by air movements from various causes. It is argued that the atmosphere is likely to have had some effects on human health and comfort, and that in ancient times, cave-dwellers (albeit on a short term basis) were likely to have confined their activities to the outer regions of the cave system.

\section{ACKNOWLEDGEMENTS}

I thank Prof. Graeme Barker, the coordinator of the Niah Caves project for the invitation to participate; the team members for their support and friendship; the Sarawak Biodiversity Centre, Kuching for a research permit and export licence; and colleagues from the Kuching museum for their constant support.
Correspondence to: Prof. F B Pyatt, Interdisciplinary Biomedical Research Centre, School of Science, The Nottingham Trent University, Clifton Lane, Nottingham NG1 1 8NS, UK; brian.pyatt@ntu.ac.uk

Accepted 11 January 2003

\section{REFERENCES}

1 Cranbrook Earl of, Lim CK. Cave swiftlets. In: Smythies BE, ed. Birds of Borneo, 4th edn (revised Davison GW). Kota Kinabalu, Sabah, Malaysia: Natural History Publications (Borneo), 1999:75-101.

2 Cranbrook Earl of, Currant AP, Davisin GW. Quaternary mammal fossils from Borneo: stegodon and hippopotamus. Sarawak Museum Journal 2000;LV(76):215-33.

3 Barker G, Barton H, Beavitt P, et al. The Niah Caves Project: a preliminary report on the first (2000) season. Sarawak Museum Journal 2000;55(76): 111-49.

4 Barker G, Badang D, Barton $\mathrm{H}$, et al. The Niah Cave Project: the second (2001) season of fieldwork. Sarawak Museum Journal 2001;57(77):37-119.

5 Brothwell D. Upper Pleistocene human skull from Niah Caves, Sarawak. Sarawak Museum Journal 1960;9(15-16):323-50.

6 Harrisson B. Niah's Lobang Tulang ("Cave of bones"). Sarawak Museum Journal 1958;8(12):596-619.

7 Harrisson B. "Cave of Bones" - new finds, 1959. Sarawak Museum Journal 1959:9(13-14):164-78.

8 Harrisson T. The Great Cave of Niah: a preliminary report on Bornean prehistory. Man 1957;57:161-6.

9 Harrisson T. The Caves of Niah: a history of prehistory. Sarawak Museum Journal 1958;8(12):549-95

10 Harrisson T. Radio carbon $\mathrm{C}^{14}$ datings from Niah: a note. Sarawak Museum Journal 1959;9(13-14):136-42.

11 Harrisson T, Medway G. A first classification of prehistoric bone and tooth artifacts based on material from Niah Great Cave. Asian Perspectives 1962:6:219-29.

12 Miner S. Preliminary air pollution survey of ammonia. US Department of Health, Education and Welfare, Public Health Service, National Air Pollution Control Administration. Raleigh, North Carolina, USA (Contract PH 22-6825).

13 Dewey CE, Cox B, Leyenaar J. Measuring ammonia concentrations in the barn using the Draeger ${ }^{T M}$ and pHydrion ${ }^{\text {TM }}$ tests. Swine Health and Production 2000;18:127-31

14 Silverman L. Physiological responses of Man to ammonia in low concentrations. Journal of Industrial Hygiene and Toxicology 1949;31(2):74-8

15 Jacobs MB. Health aspects of air pollution from incinerators. Proceedings of the National Incinerator Conference, New York, USA, 1964. American Society of Mechanical Engineers Committee.

16 Friberg L. Studies on absorption of and reaction to inhaled particles. Stockholm, Sweden: Institute of Hygiene, Karolinska Institute.

17 Caplin M. Ammonia gas poisoning: 47 cases in a London shelter. Lancet $1941 ; 2: 958-61$.

18 O'Kane J. Inhalation of ammonia vapour. A report on the management of eight patients during the acute stages. Anaesthesia 1983;38:1208-13.

19 Arwood R, Hammond J, Ward GG. Ammonia inhalation. J Trauma 1985;25:444-7.

20 Klein J, Olson KR, McKinney HE. Caustic injury from household ammonia. Am J Emerg Med 1985;3:320.

21 Swotinsky RB, Chase KH. Health effects of exposure to ammonia: scant information. Am J Ind Med 1990;17:515-21.

22 McFarlane DA, Keeler RC, Mizutani H. Ammonia volatilization in a Mexican bat cave ecosystem. Biogeochemistry 1990;30:1-8.

23 Schiffman SS. Livestock odors: implications for human health and well-being. Journal of Animal Science 1998;146:1343-55.

24 Kirkhorn SR, Garry VF. Agricultural lung diseases. Environ Health Perspect 2000;68:705-12.

25 Donham KJ, Cumro D, Reynolds SJ, et al. Dose-response relationships between occupational aerosol exposures and cross-shift declines of lung function in poultry workers. J Occup Environ Med 2000;36:260-9.

26 Michaels RA. Emergency planning and the acute toxic potential of inhaled ammonia. Environ Health Perspect 1999;75:617-27. 